\title{
Impact of various irrigation practices on nitrate movement in soil profile and wheat productivity
}

\author{
Shahbaz Khan ${ }^{1} \cdot$ Syed Karamat Abbas ${ }^{2} \cdot$ Sohail Irshad $^{3} \cdot$ Syed Adnan Mazhar ${ }^{2} \cdot$ Sumaira Batool $^{4}$
}

Received: 24 February 2020 / Accepted: 19 May 2020 / Published online: 30 May 2020

(c) The Author(s) 2020

\begin{abstract}
Nitrate is important for plant nutrition and is considered as an index of soil fertility. Its leaching to underground water not only poses severe threat to environment but also to human health. Amount of water supplemented to crops have significant role in yield and nitrate distribution in soil. An experiment was carried out to evaluate the effect of different irrigation rates on nitrate movement, soil properties and wheat yield. Experiment was laid out in randomized complete block design with three replicates. Three irrigation levels applied were $I_{1}\left(0.5 \mathrm{ET}_{0}\right.$ deficit irrigation), $I_{2}\left(1.0 \mathrm{ET}_{0}\right.$; according to farmer's practice) and $I_{3}\left(1.5 \mathrm{ET}_{0}\right.$; over irrigation). Wheat (Sehar-2006) was used as test crop. Irrigation levels had significant effects on most of growth and yield parameters of wheat. Maximum number of leaves per plant, 1000-grain weight and grain yield were observed in second irrigation level. Irrigation rates had significant effect on infiltration rate and soil saturated hydraulic conductivity, and a decrease in value of these parameters was observed in $I_{3}$ that was mainly due to higher moisture contents. Bulk density and porosity of the soil remained unchanged under various treatment applied.
\end{abstract}

Keywords Irrigation $\cdot$ Infiltration rate $\cdot$ Nitrate $\cdot$ Hydraulic conductivity $\cdot$ Bulk density $\cdot$ Porosity

\section{Introduction}

Nitrogen is considered as an essential part of agriculture and has been reported to boost the grain yield of many cereal crops (Ehdaic et al. 2010). Nitrogen can be taken up with water by crops. In modern agriculture, it is fully understood that water and nitrogen have an interactive relationship and irrigation significantly affects nitrogen status in the soil and low efficiency of fertilization (Peoples et al. 1995). Under current agricultural practices, there appears to be a shortage of both water and fertilizer. Meanwhile increasing population and restricted irrigation facilities for agricultural lands

Sohail Irshad

sohailuaf99@gmail.com

1 Department of Agronomy, Ghazi University, Dera Ghazi Khan, Pakistan

2 Institute of Soil and Environmental Sciences, University of Agriculture, Faisalabad, Pakistan

3 In-Service Agricultural Training Institute, Rahim Yar Khan, Pakistan

4 Department of Botany, University of Agriculture, Faisalabad, Pakistan always demands a priority for the production of excessive food.

Enhanced $\mathrm{N}$ fertilization not only reduced nitrogen use efficacy but also increase the loss of $\mathrm{N}$ in the form of $\mathrm{NO}_{3}$ leaching ultimately polluting the ground water in intensive farming regions (Hu et al. 2005). There are many sources of nitrate to pollute ground water, but agriculture is the most important source of ground water-pollution mostly caused by unnecessary use of $\mathrm{N}$ fertilizers; especially in intensive cropping systems like wheat, maize and potato (Ladha et al. 2005). The nitrogenous fertilizers are nitrified into $\mathrm{NO}_{3}$, and due to a negative charge (anion) and excessive water application this element could leach down gradually resulting in contaminated groundwater (Spalding and Exner 1993). Nitrate leaching is a multifaceted process and is affected by many factors like $\mathrm{N}$ fertilizer content, cropping system, soil type, tillage, irrigation methods and irrigation intensity. Two most important factors are fertilizer and irrigation rates; these both affect nitrate movement in direct way as increasing rates give elevated nitrate leaching. Drinking water is contaminated with nitrate, and this is a growing issue worldwide. Nitrate pollution in ground water was studied in many developed countries and reported as a very severe problem (Chen et al. 2005). The presence of high concentrations 
of nitrate in rivers and oceans cause a negative effect on marine ecosystems, with the production of anoxic zones and eutrophication of aquatic environments (Diaz 2001).

Wheat is a shallow-rooted crop, which can extract nitrate below root zone under greater irrigation and rainfall. From the applied nitrogen to the soil, only $50 \%$ is absorbed by plants and the remaining goes to environment through different pathways, i.e., leaching, volatilization and denitrification (Craswell and Godwin 1984). N loss from agricultural land through leaching can reduce crop yields and enhance negative environmental impacts such as eutrophication (Brady and Weil 2008).

Nitrate leaching can be improved by precision agriculture and application of fertilizer according to plant requirement; it was concluded by Marcelino et al. (2011) after determining the role of precision agriculture in reduction in nitrate leaching. Excessive use of $\mathrm{N}$ from optimum level causes greater $\mathrm{NO}_{3}{ }^{-}$losses, and it is related to applying $\mathrm{N}$ and its uptake in grain (Lord and Mitchell 1998). Split application and optimum amount $\left(180 \mathrm{~kg} \mathrm{~N} \mathrm{ha}^{-1}\right)$ of fertilizer lowered the leaching loses (Liang et al. 2011). This study was conducted with following objectives; (1) to quantify $\mathrm{NO}_{3}{ }^{-}$movement in soil profile at different irrigation levels, (2) to assess the irrigation level where $\mathrm{NO}_{3}^{-}$leaching was minimum without compromising the yield, (3) to check the effect of irrigation on soil physical properties and to evaluate the impact of irrigation on crop yield.

\section{Materials and methods}

A field study was conducted at research farm of Institute of Soil and Environmental Sciences, University of Agriculture, Faisalabad, Pakistan to evaluate the impact of various irrigation practices on nitrate movement in soil, soil properties and wheat yield. The soil of the experimental area was poor in NP contents and was calcareous in nature having $\mathrm{pH}$ 7.8. Prior to experimentation, soil samples were collected for nitrate concentration, organic carbon contents. The soil physical properties (soil bulk density, saturated hydraulic conductivity, infiltration rate) were also measured by using standard methods (Table 1). Soil was prepared for seed bed by applying two planking's followed by two ploughings. The experiment was laid out in randomized complete block design (RCBD) having three replications. There were three irrigation rates $I_{1}=0.5 \mathrm{ET}_{0}, I_{2}=1.0 \mathrm{ET}_{0}$ and $I_{3}=1.5 \mathrm{ET}_{0}$. Wheat variety (Sehar 2006) was sown as test crop. The seed rate $125 \mathrm{~kg} \mathrm{ha}^{-1}$ was used. Recommended doses of N/P/K 110,90 and $60 \mathrm{~kg} \mathrm{ha}^{-1}$ were applied, respectively. At maturity plant height was measured. Plant samples were also collected from each plot according to standard procedure.
Table 1 Physico-chemical properties of experimental soil

\begin{tabular}{lll}
\hline Parameter & Unit & Value \\
\hline E.C. & $\mathrm{dS} \mathrm{m}^{-1}$ & 1.54 \\
$\mathrm{pH}$ & & 7.84 \\
Clay & $\%$ & 28 \\
Silt & $\%$ & 23 \\
Sand & $\%$ & 49 \\
Soil texture & $\mathrm{Sandy} \mathrm{clay} \mathrm{loam}^{-3}$ & \\
Soil bulk density & $\mathrm{mg} \mathrm{m}^{-3}$ & 1.45 \\
Total porosity (pore spaces) & $\%$ & 44.73 \\
Soil infiltration rate & $\mathrm{mm} \mathrm{h}^{-1}$ & 24.97 \\
Soil hydraulic conductivity & $\mathrm{mm} \mathrm{h}^{-1}$ & 50.2 \\
Total N & $\mathrm{mg} \mathrm{kg}^{-1}$ & 0.51 \\
Soil organic matter & $\%$ & 0.41 \\
\hline
\end{tabular}

Soil bulk density was determined by core sampler's method as described by Blake and Hartge (1986).

Bulk density = Mass of oven dried soil/

Volume of soil including pore spaces

Soil particle density was determined by using pycnometer method.

Soil particle density

$=$ Mass of oven dried soil/Volume of

soil excluding pore spaces

Soil porosity was calculated by using the following formula;

Porocity $=[1-($ Bulk density $/$ Particle density $)] \times 100$

Bouyoucos hydrometer method was used to determine percentage of sand, silt and clay. Textural class was determined by following the International Textural Triangle (Ryan et al. 2001). Infiltration rate was measured with a double ring infiltrometer. Soil saturated hydraulic conductivity was measured by Guelph permeameter (Model $2800 \mathrm{KI}$ ), taking three steadystate readings. The $K_{\mathrm{fs}}$ was then calculated from the following formula;

$K_{\mathrm{fs}}=(0.0041)(X)\left(R_{2}\right)-(0.0054)(X)\left(R_{1}\right)$

where $R_{1}$ and $R_{2}$ are the steady-state rates of water fall $\left(\mathrm{cm} \mathrm{S}^{-1}\right)$ in the reservoir at the first $\left(h_{1}\right)$ and the second head $\left(h_{2}\right)$ of water $(\mathrm{cm})$, respectively, and $X\left(35.5 \mathrm{~cm}^{2}\right)$ is the reservoir constant which is related to the cross-sectional area of the combined reservoir $\left(\mathrm{cm}^{2}\right)$.

Nitrogen was determined by Kjeldahl method. Soil organic carbon was determined at up to $1 \mathrm{~m}$ depths following the method described by Ryan et al. (2001). 
\%Oxidizable organic carbon

$=\left[\left(V_{\text {blank }}-V_{\text {sample }}\right) \times 0.3 \times M\right] /[$ weight of $\operatorname{soil}(\mathrm{g})]$

\%Total organic carbon $\left(\frac{\mathrm{w}}{\mathrm{W}}\right)=1.33 \times \%$ oxidizable organic carbon

Soil Organic Carbon concentration $\left(\frac{\mathrm{g}}{\mathrm{kg}}\right)$

$=\%$ Total organic carbon $\times 10$

$M=$ Molarity of ferrous sulfate solution, $V_{\text {blank }}=$ volume of ferrous ammonium sulfate solution used for blank $(\mathrm{mL})$, $V_{\text {sample }}=$ volume of ferrous ammonium sulfate solution with soil sample $(\mathrm{mL})$.

Nitrate $-\mathrm{N}$ is measured by a spectrophotometric method (using chromotropic acid). For nitrate- $\mathrm{N}$ in soil:

$\mathrm{NO}_{3}-\mathrm{N}(\mathrm{ppm})=\mathrm{ppm} \mathrm{NO}_{3}-\mathrm{N}$

(from calibration curve) $\times(A / \mathrm{Wt}) \times(10 / V)$

where $A=$ Total Volume of the extract (mL), $V=$ Volume of extract used for measurement $(3 \mathrm{~mL}), \mathrm{Wt}=$ Weight of air-dry soil (g).

Total plant biomass, spike length, number of spikelets spike $^{-1}$, number of grains spike ${ }^{-1}$, number of tillers $\mathrm{m}^{-2}$ and grain yield were recorded at crop maturity from each experimental unit. A strip of square meter was taken from each experimental unit, and measurements were recorded. Plant height was recorded at maturity.

Harvest index is the ratio of grain weight to the total plant weight at harvest and was calculated (Sinclair 1998) as:

$\mathrm{HI}=(\mathrm{GW} / \mathrm{TPW}) \times 100$

where GW is grain weight $(\mathrm{kg})$ and TPW is the total plant weight $(\mathrm{kg})$.

\section{Statistical analysis}

The collected data were statistically analyzed by using analysis of variance (ANOVA) techniques according to RCBD. The means were compared by least significant difference
(LSD) test at $P \leq 0.05$ (Steel et al. 1997). The software packages STATISTIX 8.1 were used for statistical analysis. Data were analyzed for mean effect using two tailed Student distribution ( $T$ Test).

\section{Results}

Plant height was highest in over irrigated wheat crop which was statistically similar the crop which was irrigated following farmer practice while minimum plant height was observed in case of deficit irrigation (Table 2). Maximum spike length results from over irrigation followed by farmer practice irrigation application, while deficit irrigation resulted in lowest spike length (Table 2). Over irrigation showed maximum number of spikelets per spike which was followed by farmer practice of irrigation application, whereas deficit irrigation application produced minimum number of spikelets per spike of wheat crop (Table 2). Lowest number of grains per spike was recorded from deficit irrigation application, while farmer practice of irrigation application produced maximum number of grains per spike (Table 2). Farmer practice of irrigation resulted in maximum a productive tiller per unit area which was followed by over irrigation, however: deficit irrigation produced minimum number of productive tillers (Table 3 ). Maximum 1000-grain weight was recorded in wheat crop which was irrigated according to farmer practice, while minimum 1000grain weight was observed in deficit irrigation application (Table 3). Biological yield of wheat crop was significantly influenced by different irrigation applications. Maximum biological yield was recorded in wheat crop which was with over irrigation which was also similar to farmer practice of irrigation application, whereas deficit irrigation produced minimum total biomass of wheat crop (Table 3). Maximum grain yield was recorded in farmer practice of irrigation application which was followed by over irrigation; however, farmer practice and over irrigation resulted in similar grain yield. Whereas: minimum grain yield was noted from deficit irrigation application (Table 3). Similarly, farmer practice of irrigation application resulted in maximum harvest index of wheat crop which was similar to over irrigation, however:
Table 2 Impact of irrigation practices on plant height, spike length, spikelets per spike, productive tillers and grain per spike

\begin{tabular}{llllll}
\hline Treatments & Plant height $(\mathrm{cm})$ & Spike length $(\mathrm{cm})$ & $\begin{array}{l}\text { No. of spike- } \\
\text { lets per spike }\end{array}$ & $\begin{array}{l}\text { No. of productive } \\
\text { tillers per } \mathrm{m}^{2}\end{array}$ & $\begin{array}{l}\text { No. of } \\
\text { grains per } \\
\text { spike }\end{array}$ \\
\hline$I_{1}$ & $80.66 \mathrm{~B}$ & $10.23 \mathrm{~B}$ & $15.33 \mathrm{~B}$ & $315 \mathrm{C}$ & $46 \mathrm{C}$ \\
$I_{2}$ & $92.33 \mathrm{~A}$ & $12.06 \mathrm{~A}$ & $19.05 \mathrm{~A}$ & $339 \mathrm{~B}$ & $62 \mathrm{~A}$ \\
$I_{3}$ & $95.14 \mathrm{~A}$ & $13.56 \mathrm{~A}$ & $19.43 \mathrm{~A}$ & $365 \mathrm{~A}$ & $54 \mathrm{~B}$ \\
LSD & 7.445 & 1.803 & 2.737 & 22.32 & 7.312 \\
\hline
\end{tabular}

Means sharing the same letter did not differ significantly at $P=0.05$ 
deficit irrigation application to wheat crop produced lowest harvest index (Table 3).

There was a significant difference among various levels of irrigation applications on physical and chemical properties of soil. After harvesting of wheat crop soil analysis at soil depths of $0-25,25-50,50-75$ and $75-100 \mathrm{~cm}$ indicated that deficit irrigation application resulted in maximum soil bulk density at all depths, while lower soil bulk density was recorded from over irrigation and farmer practice of irrigation application (Table 4). Soil particle density was lowest in over irrigated wheat crop which was followed by the soil irrigated according to farmer practice of irrigation application while deficit irrigation resulted in maximum soil particle density (Table 4). After harvesting of wheat crop, soil infiltration rate was recorded maximum from over irrigated soil which was followed by the soil irrigated according to farmer practice of irrigation. Minimum soil infiltration rate was observed in the soil which was provided with deficit irrigation (Table 4). Different irrigation levels had significant influence on saturated soil hydraulic conductivity and highest soil saturated hydraulic conductivity was recorded from over irrigated soil which was similar to that of farmer practice of irrigation application, whereas deficit irrigation showed minimum soil saturated hydraulic conductivity after harvesting of wheat crop (Table 4). Maximum soil porosity was observed in over irrigated soil which was similar to farmer practice of irrigation application while deficit irrigation resulted in minimum soil porosity at wheat crop harvest (Table 4). Soil analysis indicated that after harvesting of wheat crop nitrate concentration was significantly different at soil depths of 0-25, 25-50, 50-75 and 75-100 cm in over irrigated soil, soil which was irrigated according to farmer practice of irrigation application and deficit irrigation application (Table 5). Maximum nitrate concentration at soil depth of 0-25 cm was recorded from over irrigated soil which was similar to farmer practice of irrigation, whereas deficit irrigation application in wheat resulted in minimum nitrate concentration at $0-25 \mathrm{~cm}$ soil depth (Table 5). Similarly, at soil depths of 25-50, 50-75 and $75-100 \mathrm{~cm}$ similar trend was recorded in nitrate concentration (Table 5).
Table 3 Impact of irrigation practices on 1000-grain weight, total biomass, straw yield, grain yield and harvest index

\begin{tabular}{llllll}
\hline Treatments & $\begin{array}{l}\text { 1000-grain } \\
\text { weight }(\mathrm{g})\end{array}$ & $\begin{array}{l}\text { Total biomass } \\
\text { (tons per ha) }\end{array}$ & $\begin{array}{l}\text { Straw yield } \\
\text { (tons per ha) }\end{array}$ & $\begin{array}{l}\text { Grain yield } \\
\text { (tons per ha) }\end{array}$ & Harvest index (\%) \\
\hline$I_{1}$ & $42.70 \mathrm{~B}$ & $7.45 \mathrm{~B}$ & $4.95 \mathrm{~B}$ & $3.26 \mathrm{~B}$ & $37.85 \mathrm{~B}$ \\
$I_{2}$ & $46.33 \mathrm{~A}$ & $9.81 \mathrm{~A}$ & $5.13 \mathrm{~A}$ & $4.45 \mathrm{~A}$ & $45.37 \mathrm{~A}$ \\
$I_{3}$ & $41.66 \mathrm{~B}$ & $9.59 \mathrm{~A}$ & $5.27 \mathrm{~A}$ & $3.63 \mathrm{~B}$ & $43.61 \mathrm{~A}$ \\
LSD & 3.597 & 0.629 & 0.437 & 0.627 & 5.293 \\
\hline
\end{tabular}

Means sharing the same letter did not differ significantly at $P=0.05$

\begin{tabular}{llllll}
\hline Treatments & $\begin{array}{l}\text { Bulk density } \\
\left(\mathrm{mg} \mathrm{cm}^{-3}\right)\end{array}$ & $\begin{array}{l}\text { Particle den- } \\
\text { sity }\left(\mathrm{mg} \mathrm{cm}^{-3}\right)\end{array}$ & $\begin{array}{l}\text { Soil infiltration } \\
\text { rate }\left(\mathrm{mm} \mathrm{h}^{-1}\right)\end{array}$ & $\begin{array}{l}\text { Saturated hydraulic } \\
\text { conductivity }\left(\mathrm{mm} \mathrm{h}^{-1}\right)\end{array}$ & Soil porosity (\%) \\
\hline$I_{1}$ & $1.51 \mathrm{~A}$ & $2.63 \mathrm{~A}$ & $26.66 \mathrm{~B}$ & $50.13 \mathrm{~B}$ & $42.8 \mathrm{~B}$ \\
$I_{2}$ & $1.33 \mathrm{~B}$ & $2.54 \mathrm{~B}$ & $32.02 \mathrm{~A}$ & $62.93 \mathrm{~A}$ & $47.7 \mathrm{~A}$ \\
$I_{3}$ & $1.34 \mathrm{~B}$ & $2.51 \mathrm{~B}$ & $36.11 \mathrm{~A}$ & $67.09 \mathrm{~A}$ & $48.2 \mathrm{~A}$ \\
LSD & 0.100 & 0.040 & 5.0901 & 9.877 & 4.544 \\
\hline
\end{tabular}

Means sharing the same letter did not differ significantly at $P=0.05$
Table 4 Impact of irrigation practices on bulk density, particle density, soil infiltration rate, saturated hydraulic conductivity and soil porosity 
Table 6 Impact of irrigation practices on soil organic carbon concentration at $0-25,25-50,50-75$ and $75-100 \mathrm{~cm}$ depth in the soil profile

\begin{tabular}{lllll}
\hline Treatments & $\begin{array}{l}\text { SOC }(\%) \\
\text { at } 0-25 \mathrm{~cm} \\
\text { depth }\end{array}$ & $\begin{array}{l}\text { SOC }(\%) \text { at } \\
25-50 \mathrm{~cm} \\
\text { depth }\end{array}$ & $\begin{array}{l}\text { SOC }(\%) \text { at } \\
50-75 \mathrm{~cm} \\
\text { depth }\end{array}$ & $\begin{array}{l}\text { SOC (\%) at } \\
75-100 \mathrm{~cm} \\
\text { depth }\end{array}$ \\
\hline$I_{1}$ & $0.439 \mathrm{~B}$ & $0.208 \mathrm{~B}$ & $0.122 \mathrm{~B}$ & $0.126 \mathrm{~B}$ \\
$I_{2}$ & $0.467 \mathrm{AB}$ & $0.213 \mathrm{AB}$ & $0.143 \mathrm{AB}$ & $0.127 \mathrm{~B}$ \\
$I_{3}$ & $0.509 \mathrm{~A}$ & $0.244 \mathrm{~A}$ & $0.161 \mathrm{~A}$ & $0.137 \mathrm{~A}$ \\
LSD & 0.0507 & 0.0496 & 0.0288 & 0.0131 \\
\hline
\end{tabular}

Means sharing the same letter did not differ significantly at $P=0.05$

Soil organic carbon was maximum at soil depths of $0-25$, 25-50, 50-75 and 75-100 cm in over irrigated soil which was followed by the soil irrigated according to farmer practice of irrigation application, whereas minimum soil organic carbon was recorded in the soil provided with deficit irrigation in growing season of wheat crop (Table 6).

\section{Discussion}

Outcomes of the current study depicted that maximum plant height was produced over irrigation which was statistically at par with farmer practice (Table 2). Plant height was favored as irrigation was provided to wheat crop at all critical stages of crop growth Qiu et al. (2008). The results of current study are comparable with that of Li et al. (2005) who observed that maximum number of fertile tillers were recorded when wheat crop was irrigated at crucial stages of growth, while minimum productive tillers were observed when crop was irrigated at longer intervals. Increase in plant height might be due to increase in fertilizer rates to crop that boosted vegetative growth of plants by giving proper nutrients. According to Niaz et al. (2004), increase in the rate of irrigation levels lead to higher straw yield. Higher irrigation rates result in maximum spike length (Kabir et al. 2009).

The results depict that higher number of grains per spike attained when crop is irrigated at shorter intervals, while application of irrigation at longer intervals produced less number of grains per spike. Inadequate moisture availability at mid-season resulted in less number of grains per spike while at terminal stages of plant growth higher temperature along with water scarcity negatively influence grain weight in wheat crop (Messmer et al. 2009). According to Singh and Sharma (2001), different growth parameters like plant height, no. of tillers and dry weight increased with the increased rate of $\mathrm{N}$ to wheat. Our results are in accordance with Kabir et al. (2009) who reported increase in the number of fertile tillers with increased no. of irrigations. Niaz et al. (2004) demonstrated an experiment in which he compared the HI of maize crops obtained by using irrigation. He concluded similar results as in our study that there was non-significant difference between $\mathrm{HI}$ of maize crops obtained by application of irrigation.

Hossain et al. (2004) recorded that bulk density increased significantly with soil depth, while effect of nitrogen was non-significant. Findings related to infiltration rate are in line with those of Iqbal et al. (2012). Similar trend of soil saturated hydraulic conductivity was observed by Iqbal et al. (2012). Sadej and Przekwas (2008) also observed increase in total nitrogen content with increasing $\mathrm{N}$ rates in the uppermost soil layer and soil nitrogen content decreased with soil depth. The increase in soil organic carbon (SOC) due to fertilization strategies could be due attributed to higher root biomass accumulated which might have added to the SOC particularly as indicated in the lower layers. Same trend was observed by Rasool et al. (2008) who concluded that balance amount of synthetic fertilizer can enhance SOC concentration up to $21 \%$. Similarly, Sharma et al. (2002) reported increase in SOC due to inorganic fertilization. This was due to $\mathrm{C}$ addition through the roots and crop residues (Prakash et al. 2002) over the control plots. In another study, Jagadamma et al. (2007) observed SOC pool in $0-30 \mathrm{~cm}$ depth that ranged from $68.4 \mathrm{Mg} \mathrm{ha}^{-1}$ for $\mathrm{N}_{0}$ to $75.8 \mathrm{Mg} \mathrm{ha}^{-1}$ for $\mathrm{N}_{4}$.

\section{Conclusion}

Outcomes of current experimentation depicted that number of leaves per plant, plant height and grain yield of the wheat were increased with increasing irrigation rates. Treatment $I_{2}$ produced maximum number of grains, 1000grain weight, total biomass and grain yield. Optimum level of irrigation enhanced the uptake of $\mathrm{P}$ and $\mathrm{K}$ while inappropriate application increased leaching losses. Bulk density and porosity of the soil remained unchanged under different treatment.

Acknowledgements This manuscript is extracted from thesis of M.Sc. (Hons.) Soil Science. I acknowledge the Institute of Soil and Environmental Sciences, University of Agriculture, Faisalabad, Pakistan for providing the resources including field and laboratory to conduct the research experiment.

Funding This research did not receive any specific funding.

\section{Compliance with ethical standards}

Conflict of interest The authors declare no conflict of interest. 
Open Access This article is licensed under a Creative Commons Attribution 4.0 International License, which permits use, sharing, adaptation, distribution and reproduction in any medium or format, as long as you give appropriate credit to the original author(s) and the source, provide a link to the Creative Commons licence, and indicate if changes were made. The images or other third party material in this article are included in the article's Creative Commons licence, unless indicated otherwise in a credit line to the material. If material is not included in the article's Creative Commons licence and your intended use is not permitted by statutory regulation or exceeds the permitted use, you will need to obtain permission directly from the copyright holder. To view a copy of this licence, visit http://creativecommons.org/licenses/by/4.0/.

\section{References}

Blake GR, Hartge KH (1986) Methods of soil analysis. In: Klute A (ed) Part 1. Physical and mineralogical methods, 2nd edn. Soil Science Society of America, Madison, pp 363-375

Brady NC, Weil RR (2008) The nature and properties of soil, 14th edn. Prentice-Hall, Upper Saddle River

Chen JY, Tang CY, Sakura Y, Yu JJ, Fukushima Y (2005) Nitrate pollution from agriculture in different hydrogeological zones of the regional ground water flow system in the North China Plain. J Hydrol 13:481-492

Craswell ET, Godwin DC (1984) The efficiency of nitrogen fertilizers applied to cereals in different climates. Adv Plant Nutr 1:1-55

Diaz RJ (2001) Overview of hypoxia around the world. J Environ Qual 30:275-281

Ehdaic B, Merhaut J, Ahmadian S, Hoops AC, Khoung T, Layne AP, Waines JG (2010) Root system size influences water-nutrient uptake and nitrate leaching potential in wheat. J Agron Crop Sci 196:455-466

Hossain MF, Akter MS, Majumder UK, Sikder MSI, Choudry MMAA (2004) Effect of tillage practices and $\mathrm{N}$ levels on the physical properties of soil. Pak J Biol Sci 7:1876-1879

Hu KL, Huang YF, Li LI, Li BG, Chen DL, White RE (2005) Spatial variability of shallow groundwater level, electrical conductivity and nitrate concentration, and risk assessment of nitrate contamination in North China Plain. Environ Int 31:896-903

Iqbal M, Khan AG, Hassan AU, Amjad M (2012) Soil physical health indices, soil organic carbon, nitrate content and wheat growth as influenced by irrigation and nitrogen rates. Int J Agric Biol $14: 1-10$

Jagadamma S, Rattan L, Hoeft RG, Nafziger ED, Adee EA (2007) Nitrogen fertilization and cropping systems effects on soil organic carbon and total nitrogen pools under chiselplow tillage in Illinois. Soil Tillage Res 95:348-356

Kabir N, Khan AR, Islam MA, Haque MR (2009) Effect of seed rate and irrigation level on the performance of wheat cv. Gourab. $\mathrm{J}$ Bangladesh Agric Univ 7:47-52

Ladha JK, Pathak H, Krupnik TJ, Six J, Kessel CV (2005) Efficiency of fertilizer nitrogen in cereal production: retrospects and prospects. Adv Agron 87:85-156

Li J, Inanga S, Li Z, Eneji A (2005) Optimizing irrigation scheduling for winter wheat in the North China Plain. Agric Water Manag $76: 8-23$
Liang XQ, Xu L, Li H, He M, Qian Y, Liu J, Nie Z, Ye Y, Chen Y (2011) Influence of $N$ fertilization rates, rainfall, and temperature on nitrate leaching from a rainfed winter wheat field in Taihu watershed. Phys Chem Earth 36:395-400

Lord EI, Mitchell RDJ (1998) Effect of nitrogen inputs to cereal on nitrate leaching from sandy soil. Soil Use Manag 14:78-83

Marcelino CM, Roberto UP, Rodrigo OB, Stanley BS, Natalia PV (2011) Quantifying nitrate leaching in irrigated wheat with different nitrogen stratigies in an alifisol. Chil J Agric Res 71:148-156

Messmer R, Fracheboud Y, Banziger M, Vargas M, Stamp P, Ribaut M (2009) Drought stress and wheat QTL by environment interactions and stability of QTLs across environments for yield components and secondary traits. Theor Appl Genet 199:913-930

Niaz A, Ibrahim M, Ishaq M (2004) Assessment of nitrate leaching in wheat maize cropping system. Pak J Water Resour 7:145-150

Peoples MB, Freney JR, Mosier AR (1995) Minimizing gaseous losses of nitrogen. In: Bacon PE (ed) Nitrogen fertilization in the environment. E-publishing Inc, New York, pp 565-602

Prakash YS, Bhadoria PBS, Rakshit A (2002) Comparative efficacy of organic manures on the changes in soil properties and nutrient availability in an alfisol. J Indian Soc Soil Sci 2:219-221

Qiu GY, Wang L, He X, Zhang X, Chen S, Chen J, Yang Y (2008) Water use Efficiency and evapotranspiration of winter wheat and its response to irrigation regime in the north China plain. Agric For Meteorol 148:1848-1859

Rasool R, Kukal SS, Hira GS (2008) Soil organic carbon and physical properties as affected by long term application of FYM and inorganic fertilizers in maize-wheat system. Soil Tillage Res $101: 31-36$

Ryan J, Estefan G, Rashid A (2001) Soil and plant analysis laboratory manual. In: 2nd ed. International Center for Agricultural Research in the Dry Areas (ICARDA), Alleppo, Syria, pp 46-48

Sadej W, Przekwas K (2008) Fluctuations of nitrogen levels in soil profile under conditions of a long-term fertilization experiment. Plant Soil Environ 54:197-203

Sharma SP, Subehia SK, Sharma PK (2002) Long term effects of chemical fertilizers on soil quality, crop productivity and sustainability. Research Bulletin CSK Himachal Pradesh Krishi Vishvavidhayalaya, $\mathrm{p} 33$

Sinclair T (1998) Historical changes in harvest index and crop nitrogen accumulation. Crop Sci 38:638-643

Singh DP, Sharma KN (2001) Response of wheat to nitrogen and potassium in saline soil. Exp Agric 37:417-427

Spalding RF, Exner ME (1993) Occurrence of nitrate in groundwater: a review. J Environ Qual 22:2229-2236

Steel RGD, Torrie JH, Dickey DA (1997) Principles and procedures of statistics: a biometric approach. McGraw Hill Book Co. In., New York

Publisher's Note Springer Nature remains neutral with regard to jurisdictional claims in published maps and institutional affiliations. 